\title{
Regeneration of Worn Out Machine Parts Surfaces by Automatic Welding
}

\author{
Zautomatyzowana regeneracja \\ metodami spawalniczymi \\ zużytych powierzchni części maszyn
}

\begin{abstract}
The problem of automation of regeneration processes of worn out machine parts is not an easy task since parts to be rebuilt differ from each other in means of dimensions, shape of surface, degree of wear out etc. One of the best ways to restore the nominal shape and dimensions of worn out parts is surfacing using an efficient welding process. One of the possible method of surfacing worn out machine parts automation with the use of arc welding is presented in the paper. It is based on an industrial robot installation and original procedures of parts to be rebuilt identification, measuring and surfacing with accordance to the individually generated program. The entire rebuilding procedure consisting of a several steps is performed in an automatic mode. Both, the structure of the robotic system and the principle of its operation are described in details. The system can be easily employed to an automatic rebuilding of worn machine parts of similar but not necessary the same shape, but of different state of the surface wear out. An example of industrial implementation of the described system is also presented.
\end{abstract}

Keywords: automation, regeneration, welding robot

\section{Streszczenie}

Automatyzacja procesów regeneracji zużytych części maszyn nie jest łatwa z uwagi na różnice wymiarów, kształtu, stopnia zużycia itd. Jednym z najlepszych sposobów na przywrócenie nominalnych kształtów i wymiarów zużytych części maszyn jest napawanie. W artykule przedstawiono jedną z możliwych metod, wykorzystującą zautomatyzowane napawanie łukowe.

Oparto ją na robocie przemysłowym z oryginalną procedurą identyfikacji zużytych części, pomiaru stopnia zużycia i napawania zgodnie z indywidualnie generowanym programem. Wieloetapowa procedura regeneracji odbywa się w sposób zautomatyzowany. Szczegółowo omówiono strukturę stanowiska oraz istotę jego działania. System może być z łatwością wykorzystany do automatycznej odbudowy zużytych części maszyn o podobnym kształcie, ale o innym stanie zużytej powierzchni. Przedstawiono przykład przemysłowego zastosowania omówionego systemu.

Słowa kluczowe: automatyzacja, regeneracja, robot spawalniczy

Dr hab. inż. Andrzej Kolasa prof. PW, dr inż.Tadeusz Sarnowski - ZAP Robotyka, dr inż. Paweł Cegielski - Politechnika Warszawska. 


\section{Introduction}

Automation of welding processes is nowadays not a difficult task since many ready to be used in practice solutions are offered on the market. Most of them use five or six axis industrial robots equipped with appropriate welding apparatus and necessary auxiliary arrangements. Many companies that supply industrial robots offer tailor made installations ready to use for particular application. This is easy to be implemented into practice in case of manufacturing new products or constructions where both joining or surfacing processes are to be used $[1 \div 4,6]$. More complex problems occurs if the same welding processes are to be applied for regeneration of worn out machine or technical equipment parts that are of not repeatable shape and dimensions depending of exploitation conditions resulting in various degree of surface damage. The best method of regeneration of such parts is surfacing with the use of arc welding process. Surfacing for rebuilding machine parts is the process of weld metal deposition on worn part surfaces in order to restore their nominal shape and dimensions assuring the quality and properties at least the same as the brand new parts. The surfacing allows reconditioning of parts that have been subjected to wear, corrosion, chipping off or breaking out a surface section during service. The relatively wide application of the surfacing with the use of welding processes is the result of availability of welding equipment, availability and variety of filler materials, high productivity and the process economy. The best results of the surfacing process can be obtained by its mechanization or automation. For this purpose a kinetic system that can reproduce previously programmed or adjusted movements of the work or the welding torch is used. Therefore, such mechanized systems are suitable for cylindrical or flat work surfaces.

In practice, there are a great number of parts of intricate shape that are subjected to wear due to heavy service conditions and are to be surfaced for rebuilding their nominal shapes and properties. The surfacing process automation of intricate shape parts, necessary in such cases, is possible with the use of industrial robots and the most suitable surfacing method is GMA welding. The welding robot high repeatability, productivity and economic efficiency, beside its natural flexibility, are also applicable to the robotic surfacing systems.

The robotic GMAW surfacing installation should fulfill the following requirements:

- it should assure the possibility of depositing filler metal on the whole outer surface of the work or only on its selected areas,

- the surfacing process should produce the beads of the same cross-section dimensions depended on electrode wire diameter and welding process parameters,
- the surfacing process should assure the restoration of the work parts to their nominal shapes and dimensions within specified tolerances,

- the surfacing process parameters and kind of filler materials have to assure high quality, faultless surfacing layers with an optimal dilution as well as multilayer deposit welding without necessity of any interbead or interlayer operations,

- the entire surfacing installation should be an environmental friendly system.

The all listed above requirements are fulfilled by the automatic GMAW surfacing system with an at least 5 -axis industrial robot.

Such solution has been designed, produced and implemented to a several industry companies as a result of cooperation between the Welding Engineering Department of Warsaw University of Technology and an industrial partner company, ZAP Robotics Ltd. - the manufacturer and integrator of industrial robotic installations $[5,7]$.

\section{The automatic system for regeneration worn out parts by GMAW surfacing}

The basic configuration of the automatic installation for rebuilding worn machine parts is shown in fig. 1. The main component parts of the installation are: the industrial 5-axis robot, the welding GMA equipment, the positioning table with two turntables and the work fixture arrangement on them, two work tools, i.e. the laser sensor measuring head and the welding GMA torch as well as auxiliary accessories, that make the entire system fully productive. First installation are based on IRp- 6 robots $[5,7]$ that later on were replaced by Fanuc Arc-Mate 100iC.

The work tool, either the laser sensor head or the welding torch is fixed to the robot arm with the use of the anti-collision tool holder with impact sensors. The IRp- 6 robot has five servo-driven motion axes with repeatability less than $\pm 0.2 \mathrm{~mm}$, and the handling capacity of $6.0 \mathrm{~kg}$. The robot controller consists of the microcomputer, the memory unit and binary input/ outputs for connection with other system devices and inner and outer motion axes control modules.

The parts to be surfaced are fixed on two turntables of the positioning table $\mathrm{PH}-2-100$. Both turntables can operate in either the horizontal or the vertical position, depending on the work positioning needed for the surfacing process suitability. The positioning table, being outer robot motion axes, is controlled by the robot controller with the same as inner axes positioning repeatability, that is $\pm 0.1 \mathrm{~mm}$ on dia. $1000 \mathrm{~mm}$. By controlling all inner and outer motion axes with the same robot controller, the good synchronization can be easily obtained. Two turntables allow both operations, i.e. 


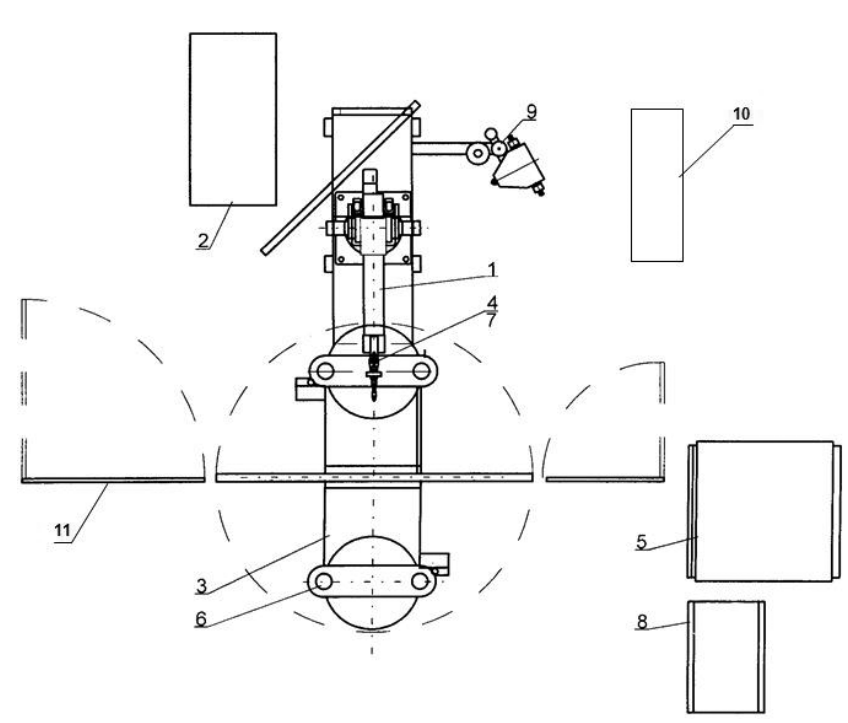

Fig. 1. The robotic surfacing installation for automated rebuilding of worn machine parts: (1) industrial robot manipulator, (2) welding power source, (3) positioning table, (4) anti-collision tool holder, (5) robot controller with build-in master controller of the entire installation, (6) work fixture, (7) laser sensor head or welding torch, (8) positioning table controller, (9) torch cleaner and wire tip cutter, (10) store of work tools. (11) welding shields.

Rys. 1. Stanowisko zrobotyzowane do automatycznej odbudowy zużytych części maszyn: (1) robot przemysłowy, (2) spawalnicze źródło zasilające, (3) pozycjoner, (4) złącze antykolizyjne, (5) układ sterowania robota z systemem nadrzędnym, (6) oprzyrządowanie montażowe, (7) czujnik laserowy, (8) układ sterowania pozycjonera, (9) stacja ucinania drutu i czyszczenia dyszy gazu osłonowego, (10) magazyn narzędzi, (11) osłony spawalnicze

the surfacing and the fixing/removing to run at the same time, on the first one, standing in the working position and the second one in the service position respectively. Such solution increases productivity of the installation and removes the operator out of the welding zone. The operator work conditions and environment can be further improved by the application of a welding shields system.

Particular attention must be paid to the design of the fixing devices. In most cases the rebuilding process of worn parts by arc surfacing is a long lasting process, that results in an extensive heating up of the work part and of the fixing device to high temperatures. This may cause the thermal expansion of their volume and dimensions changing clamping forces, etc. Therefore, the fixing clamps should have some spring elements, as e.g. spring washers, and should be made of materials of low thermal expansion coefficients.

The surfacing process is directly performed by the GMAW microcomputer controlled synergic power source can supply both constant and pulsed current up to 500 amps with an option to store in the memory unit up to 49 setups of welding parameters, called weIding programs. The power source is equipped with the separate fully stabilized wire feeder and the watercooled machine welding torch. The 4-rolls wire feeder allows for welding with solid or cored electrode wires. The welding equipment controller is connected to the robot controller with an interface using its own input and output systems that allow their mutual communication.

The robot operates using two working tools during the whole sequence of a work part surfacing. The surfacing sequence consists of two main steps. During the first one, when the part is identified and the thickness of worn out metal measured, the laser sensor head is used. The principle of operation of the laser sensor, that is used in this application for precise line distant measurement is explained in fig. 4. During the second step, when the part is surfaced, the robot uses the weIding torch.

To ensure the proper automatic performance of the welding equipment an auxiliary devices, such as wire tip cutter and welding torch cleaner with lubrication of the torch gas nozzle are necessary. The cutting off of the electrode wire tip after each surfacing operation makes the arc reignition at the beginning of the next surfacing operation sure and easy. The gas nozzle of the welding torch has to be cleaned and lubricated as often as it is required by the amount of spatter being produced during the welding process.

Since the entire robotic surfacing installation consists of a number of equipment and devices with their own control systems, including three microcomputers in the robot, the laser sensor, and the welding power supply controllers, the exact synchronization of their operation is of great importance. The responsibility for this task is left to the master controller, equipped with the master computer, while other computer controllers of the installation component devices play the slave computer role.

\section{The automatic surfacing procedure of worn out machine parts}

The procedure of the automatic surfacing with GMAW process of worn out machine parts with the use of the described above robotic system consists of the following phases:

- fixing the part to be surfaced on the positioning turntable in the service position and turn it to the work position,

- identification of the part to be surfaced,

- measurement of the thickness of worn out metal on the part surface,

- analysis of the measurement data and generation of the surfacing program tailored for the measured part,

- surfacing for rebuilding the worn out material of the part to reach the nominal shape and dimensions,

- moving the positioning table from the work to the service position and removing the rebuilt part.

All the listed above phases are run automatically. The only operations that have to be done manually are fixing the work part on the positioning table at the 
beginning of the whole procedure, removing the part after surfacing and, if necessary, maintaining emergency cases.

The surfacing procedure begins when the part is fixed and the type of the part option is chosen from the master computer menu with the use of the computer mouse or the keyboard. Once the chosen option confirmation is completed, the procedure of the second phase begins, i.e. the identification of the work part to be surfaced being fixed on the turntable. The master controller sends the command to turn the positioning table from the service to the work position. At the same time the robot manipulator takes out from the tool store the laser sensor head and moves it to the starting point. After receiving all necessary confirmations that all component devices of the installation are ready to service, the master controller activates the preliminary measurement operation. The aims of the work part preliminary measurement are: (1) to verify if the work part fixed on the positioning turntable is of the same kind as has been previously chosen by the operator, and (2) to locate the work part in the working space of the robot arm. The correct space location of the work part to be surfaced is an essential problem that has to be solved to ensure a good result of the rebuilding process.

Parts to be rebuilt by surfacing may have some points on the outer, not worn surfaces, which were machined during the course the part was manufactured. These points may serve as reference points for the purpose of the part location in the robot arm operating space. That is the best case that allows for high accuracy of the part after completion of the rebuilding process.

If parts to be rebuilt by surfacing do not have such reference points, the space location must be done with the reference to non-machined outer work part surfaces not damaged by wear, or of the lowest surface wear. In such cases the master controller system software must assist the space location of the work part. This needs the part to be preliminary measured by the laser sensor head and obtained results to be compared with nominal dimensions of the new part written and stored in the system database. This solution is time consuming and may cause some errors of the part shape restoration by rebuilding. Nevertheless it can be successfully applied for the rebuilding of parts that are subjected to further machining or if some inaccuracy in restoring their nominal shape and dimensions can be acceptable.

After the part has been identified, positively verified and its space location defined, the master controller activates the next phase of the measurement of the thickness of worn out metal. Basing on results of the preliminary measurement and information stored in the master computer database, the measuring program is generated, transferred to the robot controller and initiated. The measuring program of the work part consists of a number of readings of the line distance between the part surface and the laser head taken during the scanning of the surface by the laser sensor head along parallel lines. The measuring results are gradually transmitted to the master controller memory and visualized on the master controller monitor as a 3D image of the scanned surface. Once the measuring operation is completed the robot manipulator gives the laser head back to the tool store.

The next phase starts with the analysis of the data collected during the measuring operation. The results of the measurement are subjected to the following transformations:

- filtering interference and false measurements,

- comparing measuring results with nominal dimensions of the part from database,

- splitting the loss of metal (the thickness of worn out metal) into surfacing layers to be built-up,

- dividing each surfacing layer into single beads.

Splitting the amount of metal to be deposited into layers and each layer into surfacing beads is done with the reference to the previously declared and written in the memory of the master computer all cross-section dimensions of the single layer and the single bead. Every step of the data transformation is shown on the master computer monitor as the map of the part surface with the layout of surfacing beads.

After the measuring data has been processed, the surfacing program is generated and transmitted to the robot controller. The surfacing control program consists of surfacing operations as well as other accompanying operation, such as the work part positioning, torch gas nozzle cleaning, electrode wire tip cut-off, etc. All these operations are controlled and monitored by the master controller.

The next phase in the automatic surfacing procedure is the rebuilding up of the worn out metal by the surfacing with the use of welding. It begins with taking the welding torch out from the work tool store, switching on the welding power supply, shielding gas flow and the wire feeder. Start of each surfacing bead requires the confirmation of the welding arc ignition and then the surfacing process can be proceeded. The building up starts at the deepest area (the greatest loss of metal due to wear). Next layer is spread on a larger area of the part surface being rebuilt. In most cases the last, outer layer is deposited on the whole surface of the work part. The cross-section dimensions of each surfacing bead and layer are kept constant due to the full stabilization of all the process parameters, such as: the welding current, the welding voltage, the wire feed speed, the welding speed, the constant electrode stick-out, etc.

Once the surfacing procedure is completed the robot arm places the welding torch back in the tool store, the positioning table moves to the service position and the rebuilt part is removed out of the fixture. The robotic installation is ready for the surfacing of the next worn part to be rebuilt. 


\section{The example of industrial implementation of the automatic surfacing system}

The described here robotic installation and the automatic procedure of worn parts surfacing has been for the first time implemented for the rebuilding of chain links of an excavator shovel working in brawn coal mine (fig. 2,3). The outer dimensions of the chain links and their weight are (length $\mathrm{x}$ width $\mathrm{x}$ thickness) $680 \times 160 \times 45 \mathrm{~mm}$ and $22 \mathrm{~kg}$ for the side chain link and $680 \times 160 \times 118 \mathrm{~mm}$ and $69 \mathrm{~kg}$ for the mid chain link respectively.

The chain links are subjected to heavy wear during service due to the abrasion action by sand and mineral particles. The worn-out metal should be rebuilt up by surfacing with GMAW process. The rebuilding process

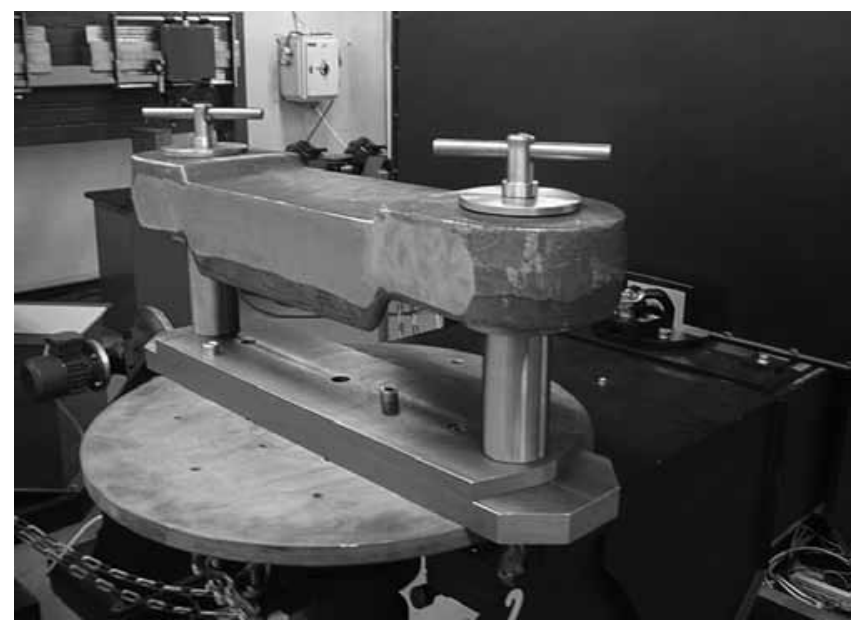

Fig. 2. An example of regenerated part fixed on the of the positioner turn table

Rys. 2. Przykład części przeznaczonej do regeneracji zamocowanej na stole pozycjonera

a)

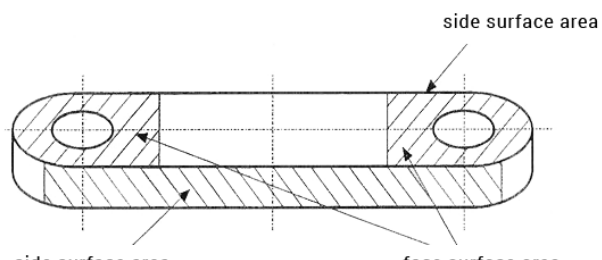

side surface area

face surface area

side surface area

b)

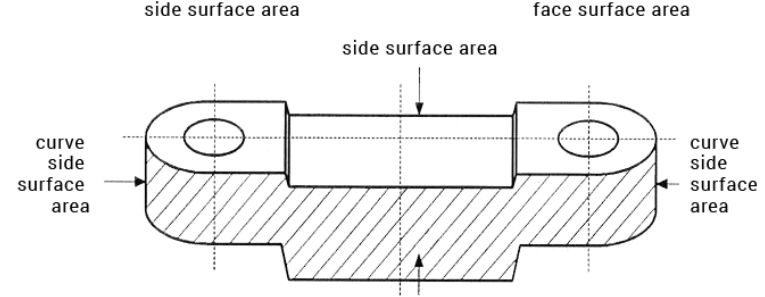

side surface area

Fig. 3. The chain links of the excavator shovel: (a) the side chain link and (b) the mid chain link with marked worn surface areas to be surfaced for rebuilding

Rys. 3. Ogniwa łańcucha koparki: (a) ogniwo boczne, (b) ogniowo środkowe z zaznaczonymi zużywającymi się powierzchniami przeznaczonymi do odbudowy comprises surface areas as marked in fig. 3 , surface welded with the use of the described above robotic installation. Other surface areas to be rebuilt, like inner areas in holes are surfaced on another welding stand.

\section{The measurement of worn chain links surface areas} to be rebuild

The measuring operations of the depth of worn out metal on outer surfaces are done by a touchless method with the use of the laser sensor head with the required accuracy. Reasonably good results have been obtained by the application of semiconductor laser sensors $[8,9]$. The principle of operation of the sensor is shown in fig. 4 .

a)
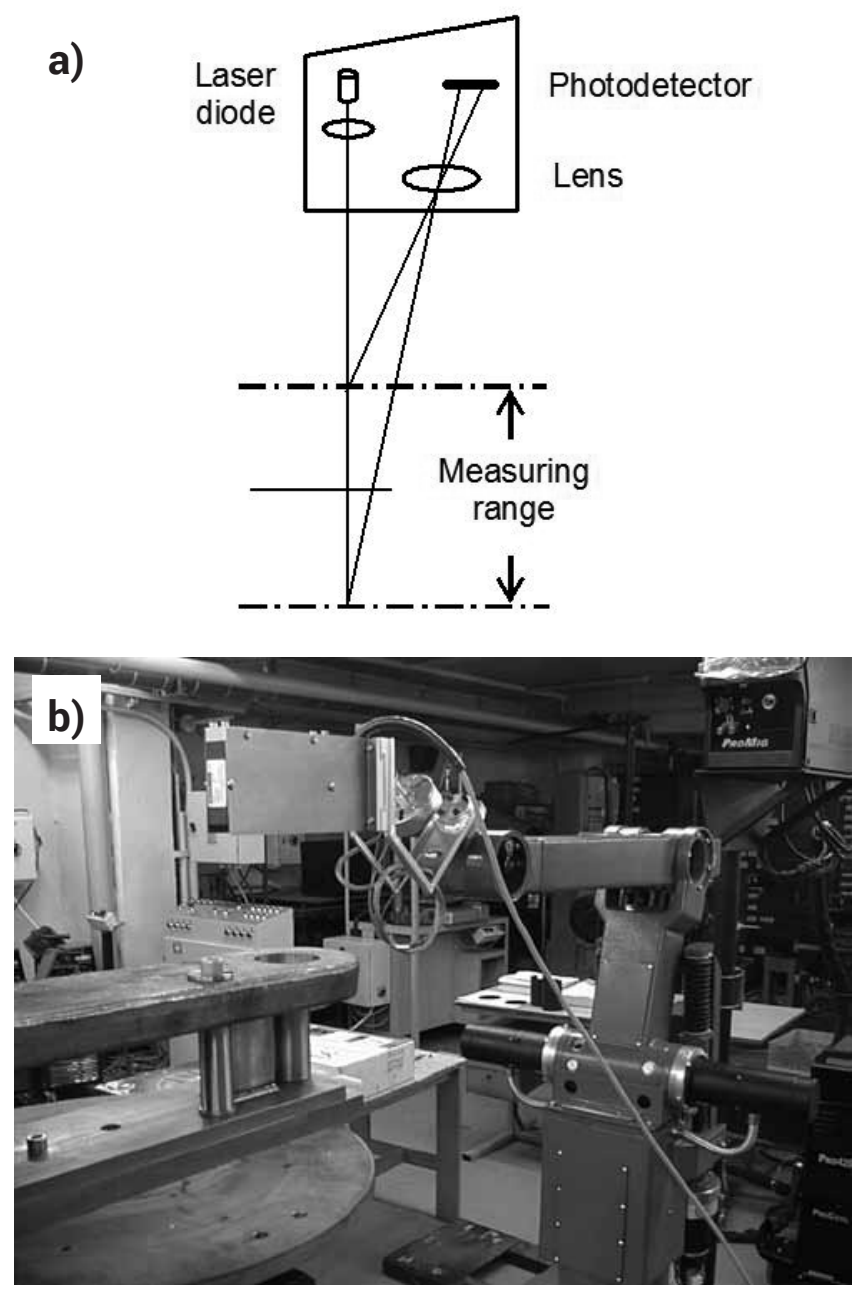

Fig. 4. The principle of operation of the laser sensor (a) and an overview of the sensor being fixed on the IRp- 6 robot arm (b)

Rys. 4. Schemat czujnika laserowego (a) oraz widok czujnika zamocowanego na ramieniu robota IRp-6 (b)

The laser ray emitted by the laser diode is reflected from the work part surface at the point of measurement and focused on the photodetector. Depending on the line distance between the laser diode and the measuring point the laser ray is focused on various locations on the photodetector plate, which generates the voltage signal related to the ray location. The signal is processed and analyzed by the microprocessor 
system and next transmitted to the master controller. The time of measurement is short enough to obtain the measuring repeatability of several thousands per second. The number of measurement readings has to be limited by the time of data transmission. The measuring accuracy of $10 \mu \mathrm{m}$ is relatively high, comparing with the robot positioning repeatability of $\pm 0.2 \mathrm{~mm}$. The surrounding lighting condition does not influence the measuring accuracy. The measuring range depends on the type of the laser sensor. That is why the selection of the type of the sensor should be based on this specific sensor property.

The laser sensor measuring head is moved by the robot arm with the constant, programmed speed along parallel measuring lines spread of $4.0 \mathrm{~mm}$ in between (fig. 5). The assumption was done, that the spread of measuring lines of $4.0 \mathrm{~mm}$ is to be related to the assumed width of the surfacing beads of $8.0 \mathrm{~mm}$ in order to allow easy calculations for the surfacing program generation purposes.

Under the above measuring conditions the number of measuring lines was as follows:

- on the face surface of the side chain link 50 lines

- on the side surface of the side chain link 10 lines

- on the face surface of the mid chain link 30 lines

- on the side surface of the mid chain link 24 lines

- on the curve side surface of the mid chain link 63 lines

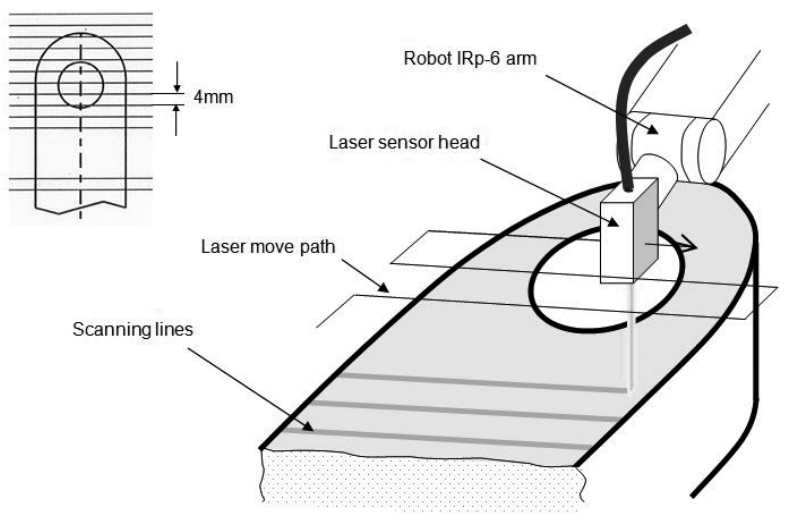

Fig. 5. The layout of measuring lines and the principle of scanning the side chain link surface by the laser sensor head

Rys. 5. Układ linii pomiarowych i zasada skanowania laserowego łącza powierzchni ogniwa bocznego

The speed of measuring readings has been so adjusted, that the measuring points along the measuring lines were at every $1.5,1.8$ and $2.0 \mathrm{~mm}$, depending on the measuring area.

One of the essential problems, deciding if the surfacing process can be performed in an automatic mode, is the accuracy of determination of the space location of each of applied tools, i.e. the laser sensor head and the welding torch as well as the mutual relation between them. The Irp- 6 robot controller has its own system procedure of the automatic definition of the torch center point TCP that ensures easy determination of all parameters necessary to define the location of the applied tool. This procedure assures the performing of both operations, i.e. the measuring and the surfacing exactly of the same work part surface area located within the robot working space.

\section{The comparison between measuring results of the work part and its nominal dimensions stored in the system database}

Most of worn chain links of the excavator shovel have relatively great metal loses on all surface areas after a certain service time. Therefore the determination of the worn out metal thickness is not an easy task. The method of this is as follow (fig. 6):

- basing on the preliminary measuring results the plane $O$ parallel to the $X Y$ plane is determined in such way, that a declared number of measuring readings is supposed to be above the plane 0 ,

- the plane 0 is moved parallelly up by the calculated length $p$, assuming that the new nominal plane $\mathrm{N}$ coincides with the chain link surface after the completion of the rebuilding operation.

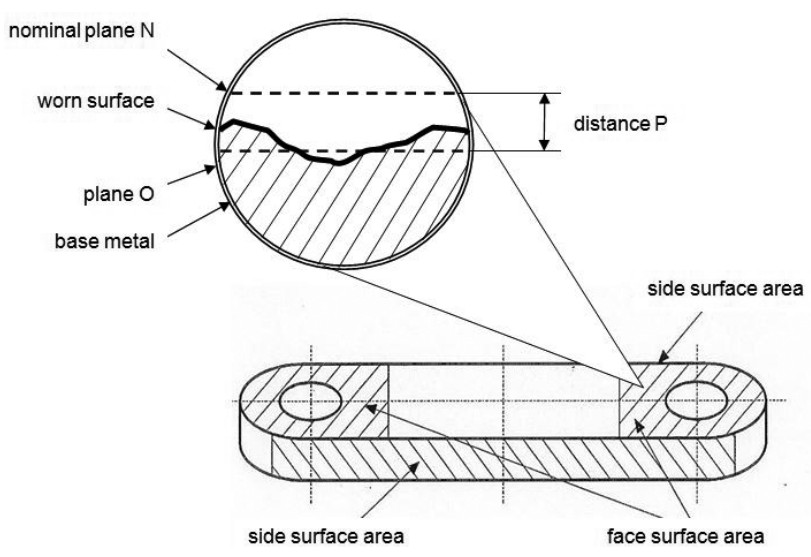

Fig. 6. The method of the determination of planes $\mathrm{O}$ and $\mathrm{N}$ respectively on the face surface of the side chain link

Rys. 6. Sposób wyznaczania płaszczyzn O i N na powierzchni czołowej ogniwa bocznego

The analysis of measuring results and the surfacing program generation by the master controller of the robotic system

The measuring results in the form of a set of line distances between the laser sensor and the measured surface along scanning lines are transmitted to the master controller. After this data system processing, the topographic map of the work part worn surface is produced and shown on the master computer monitor (fig.7). Next, the master controller generates automatically the surfacing program on the basis of the measuring data and the following assumptions: 
- each of the surfacing layer has the constant thickness of $3.0 \mathrm{~mm}$,

- each layer consists of a number of parallel surfacing beads of the constant width of $8.0 \mathrm{~mm}$ and the length not shorter than $10.0 \mathrm{~mm}$,

- surfacing beads of the upper layer are deposited in between surfaced beads of the lower one,

- the sequence of surfacing beads deposition is done in the way ensuring the lowest thermal stresses,

- the work part measurement and the surfacing process are performed along the same lines or lines parallel to each other.

The surfacing layer thickness results from the type and the diameter of the electrode wire applied. For the chain links surfacing the cored wire of dia. $2.0 \mathrm{~mm}$ was applied. It allows to produce surfacing beads and surfacing layers of the given above dimensions with the setup of typical for this wire process parameters.

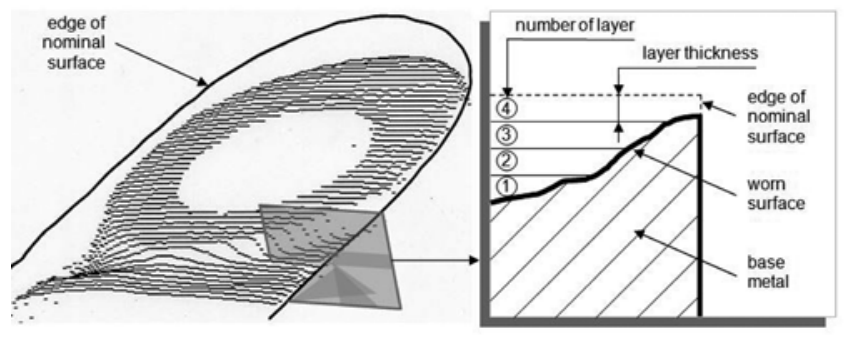

Fig. 7. The 3D image of worn surface of the chain link and the principle of the determination the number of surfacing layers

Rys. 7. Widok 3D zużytej powierzchni ogniwa i zasada określania liczby nakładanych warstw

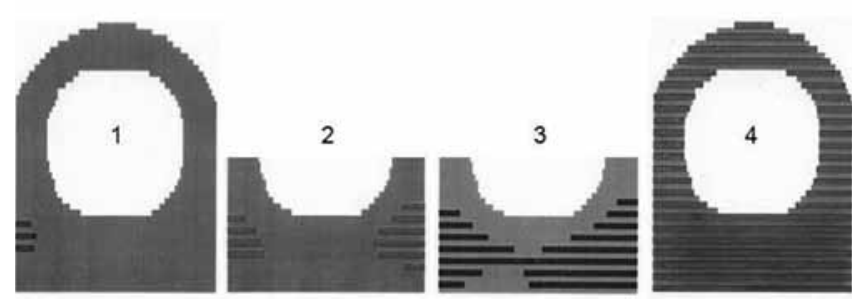

Fig. 8. The example layout of surfacing beads of surfacing layers from 1 to 4

Rys. 8. Przykładowy układ linii napawania warstw od 1 do 4

\section{The surfacing process}

The master controller determines first the deepest area, i.e. the area of the greatest loss of metal due to wear and generates the surfacing program to rebuild the first layer. When the surfacing of the first layer is completed, the area of the second layer is determined, the surfacing program is generated and next performed. The surfacing procedure is repeated until the whole worn out metal is rebuilt up, the outer layer is completed and the nominal dimensions of the chain link are restored (fig.8).

The procedure of rebuilding up all worn chain link surfaces is basically the same. Under described here process conditions, declared assumptions and procedures, the times of the measuring and the surfacing operations for the side chain links were $8.0 \mathrm{~min}$. and from 0.5 to 1.5 hour (depending on the amount of metal to be deposited), while for the mid chain links 20 $\mathrm{min}$. and from 1.5 to 4.0 hours respectively.

\section{Summary and conclusions}

The robotic system for an automatic GMAW surfacing for rebuilding worn machine parts described here has been designed as a result of the cooperation between the Welding Engineering Department of Warsaw University of Technology and the industrial company, ZAP Robotics Ltd. - the manufacturer and integrator of industrial robots installations. A number of applications of such system has been completed with the use of either IRp-6 or Fanuc industrial robots, various welding equipment as well as solid or flux cored electrode wires. The first application described here i.e. an industrial implemen- tation of the system for regeneration of worn chain links of the excavator shovel in a brown coal mine, proved the correctness of the design assumptions and the practical solutions. It has been proved, that the application of specific procedures of measuring the amount of worn-out material of work part surfaces and the specific adaptive control system allow for full automation of the surfacing process of worn machine parts of the same kind (similar shape), but of different outer dimensions, resulted from the different degree of exploitation wear. 


\section{References}

[1] Cegielski P. „Automatyzacja I robotyka w budowie maszyn” Oficyna Wydawnicza Politechniki Warszawskiej, Warszawa 1997.

[2] Kolasa A, Cegielski P. „Fully Automatic GMAW System” Proceedings of 7th International Conference on Computer Technology in Welding, San Francisco, USA, 1997, pp. 403-410.

[3] Kolasa A, Cegielski P, Sarnowski T. „Krajowe stanowisko zrobotyzowanego spawania metodą MIG/MAG" Przegląd Spawalnictwa 12/1998, s. 3-6.

[4] Kolasa A, Cegielski P, Sarnowski T. „Robotic MIG/MAG WeIding" Proceedings of VI International Conference CO-MATTECH'98, Trnava, Slovakia, 1998, pp. 452-458.

[5] Cegielski P, Kolasa A, Sarnowski T „Zrobotyzowane napawanie regeneracyjne części maszyn ze sterowaniem adaptacyjnym" Prace Naukowe Instytutu Technologii Maszyn i Automatyzacji Politechniki Wrocławskiej, Nr 78/36, tom 2, 35-38, Wrocław 2000.

[6] Kolasa A, Cegielski P. „Fully Automatic GMAW Installation” Proceedings of Ninth International Conference on Computer Technology in Welding, Detroit, USA, 2000, pp. 401-407.

[7] Kolasa A, Cegielski P, Sarnowski T. „Sterowanie adaptacyjne na stanowisku spawalniczym z robotem IRp-6" 42. Naukowo Techniczna Konferencja Spawalnicza „Techniki Komputerowe w Spawalnictwie", Warszawa 2000, s. 142-146.

[8] Cegielski P., Kolasa A., Golański D., Sarnowski T., Oneksiak A. "Innowacyjne rozwiązania konstrukcyjne w przemysłowych urządzeniach do automatyzacji procesów spawalniczych" Przegląd Spawalnictwa 1/2013, s. 30-35.

[9] Kruczyński M.: „Sensory i układy śledzenia spoiny na zrobotyzowanych stanowiskach spawalniczych". Przegląd Spawalnictwa $1 / 2013$, s. 36-39

\section{Zakład Inżynierii Spajania Politechniki Warszawskiej Sekcja Spawalnicza SIMP, Przegląd Spawalnictwa}

serdecznie zapraszają do udziału

\section{w 57. Naukowo-Technicznej Konferencji Spawalniczej}

\section{pod hastem \\ Innowacje w inżynierii spajania}

która odbędzie się w dniach

19-21 października 2015 r.

Tematyka konferencji obejmuje wszystkie zagadnienia naukowo-techniczne z szeroko pojętej dziedziny inżynierii spajania.
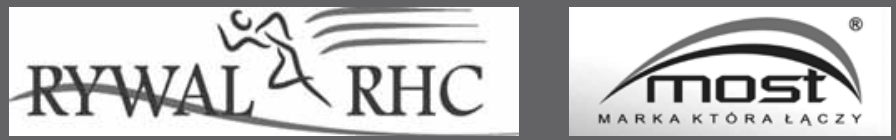

Sponsor Generalny Rywal RHC Sp. z o.o. właściciel marki MOST

Konferencja odbędzie się na terenie Windsor Palace Hotel ${ }^{* * *}$ w Jachrance oddalonej od centrum Warszawy o ok. 40 km

www.windsorhotel.pl

Informacje na temat konferencji będą umieszczane na stronie internetowej:

www.zis.wip.pw.edu.pl/konferencja

Kontakt do Organizatorów:

tel/fax: +4822 8499621; +4822 2348402 